\title{
Replacement of corn by babassu mesocarp bran in diets for feedlot young bulls ${ }^{1}$
}

\author{
Fabrícia Rocha Chaves Miotto², João Restle ${ }^{2}$, José Neuman Miranda Neiva ${ }^{3}$, Kélvia Jácome de \\ Castro $^{4}$, Luciano Fernandes Sousa ${ }^{3}$, Rafael de Oliveira da Silva ${ }^{3}$, Beatriz Barroso de Freitas ${ }^{3}$, \\ Jean Pacheco Leão ${ }^{3}$
}

\footnotetext{
${ }^{1}$ Financially supported by CNPq.

2 Universidade Federal de Goiás.

3 Universidade Federal do Tocantins.

${ }^{4}$ Universidade Federal de Minas Gerais.
}

\begin{abstract}
Nutrient intake and digestibility and productive performance of 30 feedlot young bulls fed diets containing babassu mesocarp bran in replacement of corn were evaluated. Animals were distributed in a completely randomized design with five levels of replacement of corn by babassu mesocarp bran (BMB): 0, 250, 500, 750 and $1000 \mathrm{~g} / \mathrm{kg}$ of dry matter, and six replications. The dry matter $(\mathrm{DM})$ intake in $\mathrm{kg} / \mathrm{day}, \mathrm{g} / \mathrm{kg}$ body weight $(\mathrm{BW})$ and $\mathrm{g} / \mathrm{kgBW}^{0.75}$ increased as the corn was replaced by BMB. The intake of neutral detergent fiber (NDF) and crude protein (CP) increased linearly, whereas the intake of non-fibrous carbohydrates (NFC) had quadratic behavior. The digestibility of DM, CP, NDF and NFC and the total digestible nutrients (TDN) showed quadratic behavior with points of minimum digestibility of 850.0,638.0,867.0,638.0 and $833.0 \mathrm{~g} / \mathrm{kg}$ dry matter of replacement of corn by BMB, respectively. The final weight $(476.82 \mathrm{~kg})$ and average daily gain $(1.55 \mathrm{~kg} / \mathrm{day})$ were not affected by experimental diets. The feed efficiencies of DM and CP decreased with increase in the levels of BMB, but the feed efficiency of TDN was not changed. Babassu mesocarp bran enables satisfactory performance, and depending on the price and opportunity cost, it can be utilized in the feeding of feedlot cattle totally replacing the corn of the diet.
\end{abstract}

Key Words: alternative feedstuffs, biodiesel by-products, biodiesel co-products, biofuel by-products, biofuel co-products, nutritional value

\section{Introduction}

Babassu is a palm tree of the genus Orbignya with extensive occurrence in the Brazilian territory and in several soil types, together or alternating with vegetation types such as forest, savanna, shrubbery, grassland and crops (Albuquerque, 2006). The production of babassu nuts in 2010 in Brazil was 106,055 tons (IBGE, 2011), and some of the major producing states are Maranhão, Piauí and Tocantins.

In all industrial processing methods, all components of the babassu coconut, epicarp, mesocarp and endocarp, have an economic use. Babassu mesocarp bran is a byproduct from the industrialization of babassu, which, according to Pavlak et al. (2007), has approximately $52 \%$ starch in its composition. Given the characteristics presented, the availability and nutritive potential, babassu mesocarp bran has shown to be an alternative for use in diets for cattle (Silva, 2008).

Restle et al. (2007) verified that in the finishing of feedlot beef cattle, excluding the animal price, feeding represents on average more than $70 \%$ of the total cost, and much of it is accountable to the concentrate fraction. Alternatives aiming at reduction in the costs of these components would have a more evident result in the increase of profitability of the feedlot (Pacheco et al., 2006). In this sense, the use of regional by-products as feeding for livestock shows potential to reduce the costs with the diets. Therefore, the study of the use of such feedstuffs is important for proving both the economic and biological viability. Neiva et al. (2005) state that farmers should seek the use of alternative feedstuffs aiming at reduction of production costs provided they do not impair animal performance.

The objective of this study was to evaluate the use of babassu mesocarp bran in replacement of corn on the intake and performance of feedlot young bulls and also the apparent digestibility of the nutrients of the diet.

\section{Material and Methods}

The replacement of ground corn by babassu mesocarp bran $(0,250,500,750$ and $1000 \mathrm{~g} / \mathrm{kg}$ DM of corn) in the finishing of 30 crossbred $(1 / 2$ Nellore $\times$ Dairy Brown Swiss) 
young bulls in feedlot was evaluated. The experiment was set in a completely randomized design with five treatments (levels) and six replications. Average initial age and body weight of experimental animals were $18.9 \pm 1.1$ months and $346.7 \pm 30.54 \mathrm{~kg}$, respectively. The total period of confinement lasted 105 days, with 21 days for adaptation and 84 days for experimental evaluations. Each animal occupied an individual partially covered pen $\left(12 \mathrm{~m}^{2}\right)$ with individual through and a drinker for every two pens.

Diets were formulated following the proportion of $200 \mathrm{~g} / \mathrm{kg}$ dry matter (DM) of roughage (silage of mombasa grass, Pannicum maximum Jacq. cv. Mombasa) and $800 \mathrm{~g} / \mathrm{kg}$ DM of concentrate (Table 1), with the aid of software RLM (Ração de Lucro Máximo, version 3.0), utilizing the nutritional requirements established by the NRC (1996). The mombasa grass silage presented $251.0 \mathrm{~g}$ of DM per $\mathrm{kg}$ of natural matter; and per kg of DM: $56.0 \mathrm{~g}$ of crude protein (CP); $817.0 \mathrm{~g}$ of neutral detergent fiber (NDF); $30.0 \mathrm{~g}$ of ether extract (EE); and $368.5 \mathrm{~g}$ of insoluble NDF (iNDF).

The control diet (no BMB), was formulated so as to allow for a daily gain of $1.6 \mathrm{~kg}$, without establishing specific gains for the diets with replacement of corn, meeting only the requirements of $\mathrm{CP}$ and minerals for the weight gain in question. Because of the low $\mathrm{CP}$ content of $\mathrm{BMB}$, urea was utilized to correct the $\mathrm{CP}$ content, in an attempt to make all diets contain the same amount of the nutrient; however, there was variation in the CP levels of the diets (Table 2).

The BMB utilized was produced and supplied by the company TOBASA Bioindustrial de Babaçu, located in the city of Tocantinópolis, Tocantins State, Brazil. The BMB is originated from the grinding of the mesocarp of the babassu coconut; it is one of the secondary products of the industrialization of the coconut for the removal of the nut, in which the main product is the oil. During the processing, the mesocarp and epicarp of the babassu are removed by a mechanical extraction process called peeling, which precedes the sawing of the coconut for the extraction of the nuts. After the extraction, the mesocarp and epicarp are mechanically separated by sieves with pores of varied diameters; after, the mesocarp is ground (Silva, 2008), originating the babassu mesocarp bran, product of fine granulometry and powdery aspect. The distribution of particles was evaluated for the estimate of the effectiveness of the fiber in the diets (Table 3) according to the methodology of Heinrichs \& Kononoff (2011).

Before the adaptation period, endo and ectoparasites were controlled; at the same time animals received application of vitamin supplement (ADE complex). After the adaptation period, animals were deprived of solid food for 16 hours and weighed at $8 \mathrm{~h} 00$ in the morning, so the

Table 1 - Proportion of ingredients of the experimental diets

\begin{tabular}{|c|c|c|c|c|c|}
\hline \multirow{2}{*}{ Ingredients, $\mathrm{g} / \mathrm{kg}$ dry matter (DM) } & \multicolumn{5}{|c|}{ Replacement levels of corn by babassu mesocarp bran (g/kg DM) } \\
\hline & 0 & 250 & 500 & 750 & 1000 \\
\hline Silage of mombasa grass & 200.0 & 200.0 & 200.0 & 200.0 & 200.0 \\
\hline Babassu mesocarp bran & 0.0 & 162.5 & 325.0 & 487.5 & 650.0 \\
\hline Ground corn & 650.0 & 487.5 & 325.0 & 162.5 & 0.0 \\
\hline Soybean meal & 109.3 & 109.0 & 109.0 & 109.0 & 108.0 \\
\hline Urea & 0.0 & 3.6 & 7.1 & 10.6 & 14.2 \\
\hline Limestone & 15.7 & 12.4 & 8.9 & 5.4 & 2.0 \\
\hline Mineral mix ${ }^{1}$ & 25.0 & 25.0 & 25.0 & 25.0 & 25.0 \\
\hline Mineral matter & 74.2 & 71.1 & 75.3 & 81.0 & 95.9 \\
\hline
\end{tabular}

Table 2 - Bromatological composition of the babassu mesocarp bran (BMB), corn and experimental diets

\begin{tabular}{|c|c|c|c|c|c|c|c|}
\hline \multirow{2}{*}{ Ingredients, g/kg dry matter (DM) } & \multicolumn{5}{|c|}{ Replacement level of corn by BMB, g/kg DM } & \multirow{2}{*}{$\begin{array}{c}\text { Babassu } \\
\text { mesocarp bran }\end{array}$} & \multirow{2}{*}{ Corn } \\
\hline & 0 & 250 & 500 & 750 & 1000 & & \\
\hline $\mathrm{DM}, \mathrm{g} / \mathrm{kg}$ natural matter & 739.7 & 731.7 & 732.0 & 726.9 & 724.8 & 863.0 & 887.0 \\
\hline Crude protein, g/kg DM & 111.0 & 113.5 & 116.6 & 122.2 & 127.3 & 31.0 & 97.0 \\
\hline Neutral detergent fiber $\mathrm{g} / \mathrm{kg} \mathrm{DM}$ & 307.2 & 321.5 & 367.9 & 416.7 & 457.3 & 450.0 & 163.0 \\
\hline Non-fibrous carbohydrates, $\mathrm{g} / \mathrm{kg}$ DM & 478.4 & 470.6 & 419.4 & 361.0 & 304.1 & 466.0 & 692.0 \\
\hline Ether extract, g/kg DM & 29.2 & 23.4 & 20.8 & 19.1 & 15.5 & 6.0 & 33.0 \\
\hline NDIP, g/kg CP & 225.0 & 200.0 & 176.0 & 151.0 & 126.0 & 415.0 & 330.0 \\
\hline ADIP, $\mathrm{g} / \mathrm{kg} \mathrm{CP}$ & 29.0 & 34.0 & 39.0 & 44.0 & 49.0 & 175.0 & 17.0 \\
\hline iNDF, $\mathrm{g} / \mathrm{kg}$ DM & 106.3 & 139.2 & 188.0 & 233.8 & 275.3 & 344.3 & 39.7 \\
\hline Lignin, g/kg DM & 26.5 & 51.9 & 61,7 & 78,9 & 88.5 & 115.0 & - \\
\hline Mineral matter, g/ kg DM & 74.2 & 71.1 & 75.3 & 81.0 & 95.9 & 46.0 & 160.0 \\
\hline
\end{tabular}

NDIP - neutral detergent insoluble protein; ADIP - acid detergent insoluble protein; iNDF - indigestible neutral detergent fiber. 
initial body weight and body condition score were obtained. The body condition score was assessed by two evaluators, attributing values of 1 to 5 , where: $1=$ very lean; $2=$ lean; $3=$ average; 4 = fat; and $5=$ very fat.

Feed was supplied in two daily meals: one in the morning and another in the afternoon, in which each one corresponded to $50 \%$ of the total offered daily, allowing $10 \%$ of leftovers, which were collected and weighed always in the morning. Once a week, the leftovers of each animal and the feed supplied were collected for sampling. Samples were conditioned in plastic bags, frozen and subsequently grouped proportionally in 21-day periods, forming a composite sample. All samples were pre-dried in a ventilated oven at $55{ }^{\circ} \mathrm{C}$ for 72 hours, ground in a $1 \mathrm{~mm}$ screen sieve, conditioned in plastic bottles and stored for later analyses.

The evaluation of the apparent digestibility of DM and nutrients was conducted during the last 21 days of the experimental period. For three consecutive days, feces were collected, with animals monitored from $06 \mathrm{~h} 00$ until the collection of the sample from the last animal. Three hundred grams of feces were collected during defecation before the fecal bolus reached the floor of the pen, with the aid of a collector with handle. For the digestibility trial and analysis of nutrients, samples were pre-dried in a forcedventilation oven at $55^{\circ} \mathrm{C}$ for 72 hours and ground in a $1 \mathrm{~mm}$ sieve. From the three ground samples, a composite sample was made and stored in plastic containers for subsequent laboratory analyses.

The fecal dry matter excretion was estimated by the technique of internal marker (Cochran et al., 1986), adopting the iNDF. The iNDF contents of the samples of feces, feed (roughage and ingredients of the concentrate) and leftovers were obtained after in situ rumen incubation for 240 hours. The fecal output (FO) was calculated by the formula: FO $(\mathrm{kg} / \mathrm{DM} /$ day $)=(\mathrm{iNDF} \text { intake } / \% \text { iNDF in feces })^{*} 100$. The calculation for the apparent digestibility coefficient (AD) of the nutrients was done by the formula $\mathrm{AD}=$ (nutrient ingested - nutrient excreted)/nutrient ingested.

The bromatological analyses of the feed, leftovers and feces were conducted according to techniques described by
Silva \& Queiroz (2002). Non-fibrous carbohydrates (NFC) were obtained by the equation (Hall, 2000): $\mathrm{NFC}=100-$ $[(\% \mathrm{CP}-\% \mathrm{CP}$ of urea $+\%$ urea $)+\mathrm{NDFap}+\% \mathrm{EE}+\% \mathrm{Ash}]$; the total carbohydrates (TCH), by the following equation: $\mathrm{TCH}=100-(\% \mathrm{CP}+\% \mathrm{EE}+\%$ Ash $)$. The total digestible nutrients (TDN) observed were estimated for the different diets by the equation: TDN observed $=\mathrm{DCP}+(\mathrm{DEE} \times$ $2.25)+\mathrm{DTCH}$, where $\mathrm{DCP}=$ digestible crude protein; $\mathrm{DEE}=$ digestible ether extract and $\mathrm{DTCH}=$ digestible total carbohydrates. The concentration of TDN was calculated by: $\% \mathrm{TDN}=(\mathrm{TDN}$ intake/DM intake $) \times 100($ Sniffen et al., 1992)

The Shapiro Wilk test was performed to evaluate the normality and Cochran \& Bartlett's test was used to evaluate the homogeneity of variances, with no need for transformation of the variables studied. To evaluate the effect of the levels, regression analysis was utilized, following the mathematical model: $\mathrm{Yij}=\mu+\mathrm{Si}+$ eij, where $\mu=$ overall mean, i.e., it represents a constant inherent to every plot; $\mathrm{Si}=$ the effect of the replacement levels of corn $\mathrm{i}$, where $\mathrm{i}=0,250,500,750,1000$; eij $=$ experimental error of plot ij. For probability of type I error, $\alpha=0.05$. The statistical analysis was conducted with the aid of statistical package SISVAR 5.1 (Ferreira, 2011).

\section{Results and Discussion}

The DM intake increased linearly $(\mathrm{P}<0.01)$ as the corn was replaced by BMB (Table 4). Animals fed the diet containing $1000 \mathrm{~g}$ replacement of corn per $\mathrm{kg}$ of DM consumed $2.6 \mathrm{~kg}$ more DM per day than the animals fed the control diet. This difference accounted for an increase of $31.3 \%$, and the intakes in $\mathrm{g} / \mathrm{kg}$ body weight $(\mathrm{BW})$ and in $\mathrm{g} / \mathrm{kg} \mathrm{BW}^{0.75}$ were higher by $32.7 \%$ and $32.4 \%$, respectively.

The animals probably elevated DM intake in an attempt to fulfill their requirements of energy, since with elevation in the NDF content of the diets their energy value reduced (Table 5). As the BMB was added to the diets, the percentage of particles smaller than $1.67 \mathrm{~mm}$ increased from $24.6 \%$ in the diet without BMB, to $39.9 \%$ in the diet

Table 3 - Percentage distribution of the particle size of the silage and experimental diets

\begin{tabular}{|c|c|c|c|c|c|c|c|}
\hline \multirow{2}{*}{ Particle (mm) } & \multirow{2}{*}{ Sieve pore $(\mathrm{mm})^{2}$} & \multicolumn{6}{|c|}{ Feedstuffs $^{1}$} \\
\hline & & 0 & 250 & 500 & 750 & 1000 & Silage of mombasa grass \\
\hline$>19.0$ & 19.0 & 13.1 & 13.0 & 13.6 & 13.2 & 13.2 & 24.7 \\
\hline 8.0 to 19.0 & 8.0 & 23.0 & 22.8 & 22.5 & 22.8 & 22.6 & 42.7 \\
\hline 1.67 to 8.0 & 1.18 & 39.3 & 35.4 & 31.4 & 26.7 & 24.6 & 32.6 \\
\hline$<1.67$ & - & 24.6 & 28.8 & 32.5 & 37.2 & 39.9 & 0.0 \\
\hline Average particle size & - & 6.4 & 6.3 & 6.2 & 6.3 & 6.0 & 10.4 \\
\hline
\end{tabular}

${ }^{1}$ Total diets (feed supplied to animals - roughage + concentrate), according to the proportion of replacement of corn by babassu mesocarp bran ( $\mathrm{g} / \mathrm{kg}$ dry matter).

${ }^{2}$ The pores are square, with the diagonal as the largest opening, of $1.67 \mathrm{~mm}$. This is why the largest particles able to pass through the sieve have less than $1.67 \mathrm{~mm}$ of length. 
with $1,000 \mathrm{~g} / \mathrm{kg}$ DM replacement of corn (Table 3). Among the many effects of reduction in the size of the particles of the diets, it is worth remarking the increase in their density and consequently in their passage rate, which would allow for faster emptying of the rumen.

Although it was expected that intake could be reduced with elevation in the NDF content of the diets, in the present study it did not occur, probably because of the increase in the percentage of particles smaller than $0.19 \mathrm{~mm}$. According to Mertens (1994), when feedstuffs with a high NDF content are finely ground, the DM intake increases. The same author observed that for diets in which the DM intake is limited by the energy requirements of the animals, the increase in the NDF content of the diet promotes increase in DM intake, until the physical limit of ingestion is reached. Moreover, the small part of roughage in the diet, $200 \mathrm{~g} / \mathrm{kg}$ DM of mombasa grass silage, is also a factor that contributes to the increase in DM intake, so the BMB finely ground would have little effect on rumen fill.

Silva (2008) did not verify influence from the replacement of corn by BMB on the DM intake of feedlot bulls fed diets with replacement of up to $600.0 \mathrm{~g} / \mathrm{kg} \mathrm{DM}$, observing average intake of $9.36 \mathrm{~kg} /$ day and $25.4 \mathrm{~g} / \mathrm{kg} \mathrm{BW}$. However, in the study of Silva (2008) the diets presented roughage content of $440 \mathrm{~g} / \mathrm{kg} \mathrm{DM}$, which promoted different ingestive behavior of animals by the greater amount of long fiber, wherein the diets showed more potential for rumen fill when compared with the diets of the present study.
The $\mathrm{CP}$ intake values rose linearly $(\mathrm{P}<0.01)$ as the corn was replaced by $\mathrm{BMB}$. The greater $\mathrm{CP}$ intake is explained by the increase in DM intake, as well as the variation in the $\mathrm{CP}$ contents of the diets (Table 1).

There was increase $(\mathrm{P}<0.01)$ in the NDF intake with replacement of corn by BMB (Table 4). The values observed for NDF intake, in $\mathrm{g} / \mathrm{kg} \mathrm{BW}$ of the diets with 250 , 500,750 and $1000 \mathrm{~g} / \mathrm{kg}$ DM replacement were 14.7, 42.6, 63.2 and $86.7 \%$ higher than the intake observed for the diet without BMB, respectively. The increase in the NDF intake is explained by the increase of this fraction in the diets, due to the elevated content of this component in BMB $(450 \mathrm{~g} / \mathrm{kg} \mathrm{DM})$ and due to the increase of the DMI.

The NFC intake in $\mathrm{kg} /$ day rose up to the replacement level of $467.0 \mathrm{~g} / \mathrm{kg} \mathrm{DM}$ of corn by BMB in the $\operatorname{diet}(\mathrm{P}<0.01)$ and can be explained by the increase in DM intake (DMI). After the point of maximum, there was a decrease in NFC intake due to the reduction of NFC in the diets with replacement of corn by BMB. The EE intake values decreased $(\mathrm{P}<0.01)$ in spite of the increase in DMI, explained by the decrease in the percentage of $\mathrm{EE}$ of the diets with increase in BMB (Table 2).

The TDN intake of experimental diets was not affected by the replacement levels $(\mathrm{P}>0.05)$, with an average of $6.01 \mathrm{~kg} /$ day. Since the TDN values were reduced (Table 4) with replacement of corn by BMB, it was expected that the energy would be reduced. However, the lower energy density of the diets containing $\mathrm{BMB}$ was compensated by the greater DM intake when corn was replaced by BMB.

Table 4 - Nutrient intake of feedlot young bulls fed diets containing babassu mesocarp bran in replacement of corn

\begin{tabular}{|c|c|c|c|c|c|c|c|c|c|}
\hline \multirow{2}{*}{ Items } & \multicolumn{5}{|c|}{ Replacement levels, g/kg DM } & \multicolumn{3}{|c|}{ Probabilities } & \multirow{2}{*}{$\mathrm{CV}(\%)$} \\
\hline & 0 & 250 & 500 & 750 & 1000 & Linear & Quadratic & Lack of fit & \\
\hline \multicolumn{10}{|c|}{ Dry matter $(\mathrm{DM})$} \\
\hline $\mathrm{g} / \mathrm{kg} \mathrm{BW}^{2}$ & 20.8 & 23.1 & 25.9 & 26.5 & 27.6 & $<0.001$ & 0.23 & 0.83 & 10.1 \\
\hline $\mathrm{g} / \mathrm{kg} \mathrm{BW}^{0.753}$ & 93.31 & 104.65 & 117.07 & 119.32 & 123.57 & $<0.001$ & 0.19 & 0.85 & 10.7 \\
\hline \multicolumn{10}{|c|}{ Crude protein } \\
\hline \multicolumn{10}{|c|}{ Neutral detergent fiber } \\
\hline $\mathrm{g} / \mathrm{kg} \mathrm{BW}^{5}$ & 0.68 & 0.78 & 0.97 & 1.11 & 1.27 & $<0.001$ & 0.79 & 0.80 & 9.8 \\
\hline \multicolumn{10}{|c|}{ Non-fibrous carbohydrates } \\
\hline $\mathrm{kg} / \mathrm{day}^{6}$ & 3.88 & 4.46 & 4.56 & 4.04 & 3.52 & 0.16 & 0.006 & 0.77 & 14.9 \\
\hline \multicolumn{10}{|c|}{ Ether extract } \\
\hline $\begin{array}{l}\mathrm{BW}-\text { body weig } \\
{ }^{1} \hat{Y}=8.91+0.00 \\
{ }^{2} \hat{Y}=21.4+0.00 \\
{ }^{3} \hat{Y}=96.55+0.0 \\
{ }^{4} \hat{Y}=0.95+0.00 \\
{ }^{5} \hat{Y}=0.66+0.00 \\
{ }^{6} \hat{Y}=3.92+0.00 \\
{ }^{7} \hat{Y}=0.26-0.000\end{array}$ & $\begin{array}{l}\text { fficient of } \\
4) . \\
4) . \\
\text { ). } \\
\text { 8). } \\
\text { 9). } \\
3 \mathrm{X}^{2}\left(\mathrm{r}^{2}=\right. \\
8\end{array}$ & & & & & & & & \\
\hline
\end{tabular}


The apparent digestibility of DM showed quadratic behavior $(\mathrm{P}<0.05)$, in which the lowest digestibility coefficient (0.47) was obtained with $850.0 \mathrm{~g} / \mathrm{kg}$ DM of replacement of corn by BMB (Table 5), which was the point where the values stabilized. According to Forbes (1995), finely ground materials allow for greater consumption by animals based on the greater passage rate. However, the shorter retention time in the rumen tends to decrease the digestibility of nutrients.

According to Russell \& Wilson (1996), the increase in the passage rate reduces the digestibility of nutrients, and especially, of fibrous components and low rumendegradability starch. This condition indicates that for better understanding of BMB as feed for ruminants there is need for further studies evaluating the passage rate and characterizing its NFC, once this group comprehends, according to Hall (2001), sugars, starch, fructosans, beta glucans and pectin (neutral detergent soluble fiber) and organic acid and, according to the proportion and structure, can strongly influence the rumen fermentation patterns. The lower BMB digestibility is mainly due to the greater participation of the indigestible fibrous fraction, iNDF, probably because of the elevated lignin content of this byproduct.

The CP digestibility had its lowest value at the replacement level of $638 \mathrm{~g} / \mathrm{kg}$ DM of BMB in relation to the corn $(\mathrm{P}<0.01)$. The decrease in the $\mathrm{CP}$ digestibility followed the DM digestibility, and the $\mathrm{CP}$ digestibility might have undergone both effect from the elevated lignin contents and the elevated acid detergent insoluble nitrogen content of BMB. The inclusion of urea as the BMB was added to the diets (Table 1) can explain the quadratic response of the $\mathrm{CP}$ digestibility, once as the BMB was added to the diet, the lower-digestibility protein increased, but the addition of urea aiming to correct the low protein level of BMB increased the proportion of nitrogen $(\mathrm{CP})$ readily available in the rumen, leading to an imbalance in the digestibility of the protein fraction. Thus, the digestibility reduced up to the replacement level of $638.0 \mathrm{~g} / \mathrm{kg}$ DM with stabilization from this inclusion level onwards.

The apparent NDF digestibility decreased $(\mathrm{P}<0.05)$ up to the replacement level of $867.0 \mathrm{~g} / \mathrm{kg} \mathrm{DM}$, tending towards stabilization from this point onwards. The digestibility of NDF was impaired by the elevated lignin content of BMB, $115.0 \mathrm{~g} / \mathrm{kg}$ DM. There was a decrease in the NFC digestibility $(\mathrm{P}<0.05)$ up to the level of $638.0 \mathrm{~g} / \mathrm{kg}$ replacement of corn, promoting minimum digestibility coefficient of 0.79 , with stabilization of digestibility from this point onwards.

The TDN content decreased $(\mathrm{P}<0.05)$ up to the replacement level of $833.0 \mathrm{~g} / \mathrm{kg} \mathrm{DM}$ of corn. The decrease in the TDN values of the diets was caused by the reduction in digestibility that happened in most nutrients; the lowest TDN was similar to the minimum digestibility point of NDF and DM. The reduction in digestibility of NFC and consequently in the TDN values probably occurred because of the diminution in the size of the particles of the diets (Table 3).

The final weight of the animals (Table 6) was not changed and the diets promoted similar daily weight gains $(\mathrm{P}>0.05)$. The similarity in weight gain can be explained by the similarity in TDN intake for all diets and not by the limitation in CP intake. Similar behavior was observed by Silva (2008), who did not verify influence from the replacement of corn by BMB in the finishing of Nellore bulls with diets containing concentrate of $660 \mathrm{~g} / \mathrm{kg}$ DM. Therefore, it is possible to verify that although BMB reduced the energy content of the diets, this by-product allowed for an increase of $30 \%$ in the DM intake in the diet with $1,000 \mathrm{~g} / \mathrm{kg}$ DM replacement in relation to the diet without BMB, promoting the maintenance of good results in animal performance. However, based on the increase in the dietary DM intake, it is important to evaluate the

Table 5 - Apparent digestibility coefficients of diets containing babassu mesocarp bran (BMB) in replacement of corn for feedlot young bulls

\begin{tabular}{|c|c|c|c|c|c|c|c|c|c|}
\hline \multirow{2}{*}{ Item } & \multicolumn{5}{|c|}{ Replacement levels of corn } & \multirow{2}{*}{$\mathrm{CV}, \%$} & \multicolumn{3}{|c|}{ Probabilities } \\
\hline & 0 & 250 & 500 & 750 & 1000 & & $\mathrm{~L}$ & Q & Lack of fit \\
\hline $\mathrm{ADDM}^{1}$ & 0.68 & 0.59 & 0.50 & 0.44 & 0.45 & 11.83 & 0.002 & 0.02 & 0.65 \\
\hline $\mathrm{ADCP}^{2}$ & 0.73 & 0.63 & 0.59 & 0.56 & 0.64 & 11.84 & 0.013 & 0.004 & 0.76 \\
\hline $\mathrm{ADNDF}^{3}$ & 0.47 & 0.41 & 0.29 & 0.29 & 0.32 & 25.34 & 0.001 & 0.03 & 0.53 \\
\hline $\mathrm{ADNFC}^{4}$ & 0.95 & 0.86 & 0.82 & 0.74 & 0.84 & 10.21 & 0.007 & 0.017 & 0.33 \\
\hline ADEE & 0.79 & 0.75 & 0.70 & 0.76 & 0.77 & 11.05 & 0.73 & 0.09 & 0.68 \\
\hline $\mathrm{TDN}^{5}, \mathrm{~g} / \mathrm{kg} \mathrm{DM}$ & 740 & 650 & 570 & 500 & 520 & 9.92 & $<0.001$ & 0.016 & 0.44 \\
\hline
\end{tabular}

ADDM - apparent digestibility of dry matter; ADCP - apparent digestibility of crude protein; ADNDF - apparent digestibility of neutral detergent fiber; ADNFC - apparent digestibility of non-fibrous carbohydrates; ADTCH - apparent digestibility of total carbohydrates; ADEE - apparent digestibility of ether extract; TDN - total digestible nutrients; $\mathrm{L}$ and $\mathrm{Q}$ - linear and quadratic effects regarding the inclusion of additive in the diet; CV - coefficient of variation.

${ }^{1} \hat{\mathrm{Y}}=0.685-0.00051 \mathrm{X}+0.0000003 \mathrm{X}^{2}\left(\mathrm{r}^{2}=0.99\right)$

${ }^{2} \hat{Y}=0.732-0.00051 X+0.0000004 X^{2}\left(r^{2}=0.97\right)$

${ }^{3} \hat{Y}=0.486-0.00052 \mathrm{X}+0.0000004 \mathrm{X}^{2}\left(\mathrm{r}^{2}=0.93\right)$

${ }^{4} \hat{Y}=0.956-0.00051 \mathrm{X}+0.0000004 \mathrm{X}^{2}\left(\mathrm{r}^{2}=0.87\right)$

${ }^{5} \hat{Y}=72.9-0.05 \mathrm{X}+0.00003 \mathrm{X}^{2}\left(\mathrm{r}^{2}=0.97\right)$. 
Table 6 - Performance variables of young bulls fed diets containing babassu mesocarp bran (BMB) in replacement of corn

\begin{tabular}{|c|c|c|c|c|c|c|c|c|c|}
\hline \multirow{2}{*}{ Item } & \multicolumn{5}{|c|}{ Replacement levels of corn by BMB, $\mathrm{g} / \mathrm{kg}$ dry matter } & \multirow{2}{*}{$\mathrm{CV}, \%$} & \multicolumn{3}{|c|}{ Probabilities } \\
\hline & 0 & 250 & 500 & 750 & 1000 & & Linear & Quadratic & Lack of fit \\
\hline Initial weight, $\mathrm{kg}$ & 344.2 & 352.0 & 345.0 & 346.0 & 346.8 & 9.5 & 0.98 & 0.90 & 0.90 \\
\hline Final weight, $\mathrm{kg}$ & 474.7 & 483.8 & 489.0 & 474.6 & 461.2 & 8.4 & 0.49 & 0.29 & 0.95 \\
\hline Total weight gain, $\mathrm{kg}$ & 130.5 & 131.8 & 144.0 & 128.6 & 114.4 & 18.5 & 0.26 & 0.10 & 0.64 \\
\hline Feed efficiency of DM, $\mathrm{kg}$ daily weight gain $/ \mathrm{kg} \mathrm{DM}^{1}$ & 0.185 & 0.162 & 0.150 & 0.140 & 0.123 & 13.8 & $<0.001$ & 0.95 & 0.59 \\
\hline Feed efficiency of $\mathrm{CP}$, $\mathrm{kg}$ daily weight gain $/ \mathrm{kg} \mathrm{CP}{ }^{2}$ & 1.68 & 1.45 & 1.37 & 1.16 & 0.95 & 13.1 & $<0.001$ & 0.72 & 0.62 \\
\hline
\end{tabular}

CV - coefficient of variation; CP - crude protein; DM - dry matter; TDN - total digestible nutrients.

${ }^{1} \hat{Y}=0.183-0.00005 X\left(r^{2}=0.97\right)$

${ }^{2} \hat{Y}=1.67-0.0007 X\left(r^{2}=0.98\right)$.

${ }^{3} 1=$ very lean; $2=$ lean; $3=$ average; $4=$ fat; $5=$ very fat.

relation of cost (corn/BMB) to guide the choice for the ingredient to be acquired by the farmer, since the animal performance was not changed, but there was increase in dry matter intake. Another important aspect is that when the farmer decides to use this by-product, they must include in the costs the increase in labor force for processing and feed supply, once the dry matter intake is $30 \%$ higher at the replacement level of $1,000 \mathrm{~g} / \mathrm{kg} \mathrm{DM}$.

In spite of the similarity of performance, the feed efficiency of DM decreased linearly $(\mathrm{P}<0.01)$ with increase in the levels of $\mathrm{BMB}$; for each percentage point of replacement there was a reduction of $0.5 \mathrm{~g}$ in average daily gain (ADG) for each $1 \mathrm{~kg}$ DM consumed. Because the feed efficiency relates $\mathrm{ADG}$ to $\mathrm{DM}$ intake, the decrease in efficiency occurred because of the increase in DMI (Table 4) without alterations of performance. There was a decrease of 12.4, 19.0, 24.3 and $33.5 \%$ in the feed efficiency of DM for the diets with $250,500,750$ and $1000 \mathrm{~g} / \mathrm{kg}$ DM of replacement, respectively, when compared with the diet without BMB.

The conversion efficiency of $\mathrm{CP}$ decreased $(\mathrm{P}<0.01)$ with replacement of corn by BMB (Table 6). In the control diet $1 \mathrm{~kg} \mathrm{CP}$ promoted $1.68 \mathrm{~kg}$ ADG, whereas in the diet with $100 \%$ replacement the weight gain was only $0.95 \mathrm{~kg}$. With increase in DM intake, there was increase in CP intake, but TDN did not change, so one can assume that greater weight gains for the higher levels of protein consumed were possibly limited by the energy level of the diets. According to Caldas Neto et al. (2007), the lack of synchronization of the source of protein and source of energy, or even the reduction in the energy available for use of non-protein nitrogen by the rumen microorganisms can reduce the feed efficiency. The feed efficiency of TDN did not differ among the diets $(\mathrm{P}>0.05)$, since both TDN intake and ADG were similar for all levels evaluated.

The gain in body condition was not affected $(\mathrm{P}>0.05)$, so there was no variation in the final body condition of animals. Variables such as body weight, breed group, daily weight gain, among others, have an influence in the body condition score of animals. In this study, the animals presented the same final weight, ADG, period in feedlot and genetic composition, only differing as to the energy concentration of the diets consumed. However, since the energy intake did not vary, there was no difference in the evaluation of their body condition score.

\section{Conclusions}

Babassu mesocarp bran is less efficiently utilized for weight gain, but it allows for satisfactory performance and given the circumstances of price and opportunity cost, it can be used in the feeding of feedlot cattle totally replacing the corn of the diet.

\section{Acknowledgments}

The authors thank TOBASAAgroindustrial for providing the babassu mesocarp bran and Barra Bonita Farm (PiraquêTO) for lending the animals utilized in this experiment.

\section{References}

ALBUQUERQUE, N.I. Emprego do babaçu (Orbignya phalerata) como fonte energética para catetos. 2006. 79f. Tese (Doutorado em Ciências) - UNESP, Piracicaba.

CALDAS NETO, S.F.; ZEOULA, L.M.; KAZMA, R. et al. Proteína degradável no rúmen associada a fontes de amido de alta ou baixa degradabilidade: digestibilidade in vitro e desempenho de novilhos em crescimento. Revista Brasileira de Zootecnia, v.36, n.2, p.452-460, 2007.

COCHRAN, R.C.; ADANS, D.C.; WALLACE, J.D. et al. Predicting digestibility of different diets with internal markers: evaluation of four potential markers. Journal of Animal Science, v.63, p.1476-1483, 1986.

FERREIRA, D.F. Sisvar: a computer statistical analysis system. Ciência e Agrotecnologia, v.35, n.6, p.1039-1042, 2011.

FORBES, J.M. Voluntary food intake and diet selection in farm animals. Wallingford: CAB International, 1995. 532p. 
HALL, M.B. Recentes avanços em carboidratos não-fibrosos na nutrição de vacas leiteiras. In: SIMPÓSIO INTERNACIONAL DE BOVINOCULTURA DE LEITE: Novos conceitos em nutrição, 2., 2001, Lavras. Anais... Lavras: Universidade Federal de Lavras, 2001. p.149-159.

HALL, M.B. Calculation of non-structural carbohydrate content of feeds that contain non-protein nitrogen. Gainesville: University of Florida, 2000. p.A-25 (Bulletin, 339).

HEINRICHIS, J.; KONONOFF, P. Evaluating particle size of forages and TMRs using the New Penn State Forage Particle Separator. College of Agricultural Sciences and Cooperative Extension. Department of Dairy and Animal Science - The Pennsylvania State University. Available at: $<$ http://www.das.psu. edu/research-extension/dairy>. Accessed on: May 20, 2011.

INSTITUTO BRASILEIRO DE GEOGRAFIA E ESTATÍSTICA IBGE. Anuário estatístico do Brasil. Rio de Janeiro, 2011. v.71

MERTENS, D.R. Regulation of forage intake, In: FAHEY, G.C.; COLLINS, M.; MERTENS, D.R. et al. (Eds.) Forage quality: evaluation and utilization. Madison, Wisconsin: American Society of Agronomy, Crop Science Society of America and Soil Science Society of America, 1994. p.450-493.

NATIONAL RESEARCH COUNCIL - NRC. Nutrient requirements of beef cattle. 7.ed. Washington, D.C.: National Academic of Sciences, 1996. 248p.

NEIVA, J.N.M.; SOARES, A.N.; MORAES, S.A. et al. Farelo de glúten de milho em dietas para ovinos em confinamento. Revista Ciência Agronômica, v.34, n.1, p.111-117, 2005.
PACHECO, P.S.; RESTLE, J.; VAZ, F.N. et al. Avaliação econômica da terminação em confinamento de novilhos jovens e superjovens de diferentes grupos genéticos. Revista Brasileira de Zootecnia, v.36, n.1, p.309-320, 2006.

PAVLAK, M.C.M.;ZUNIGA,A.D.; LIMA, T.L.A. et al. Aproveitamento da farinha do mesocarpo do babaçu (Orbignya martiana) para obtenção de etanol. Evidência, v.7, n.1, p.7-24, 2007.

RESTLE, J.; PACHECO, P.S.P.; COSTA, E.C et al. Apreciação econômica da terminação em confinamento de novilhos Red Angus superjovens abatidos com diferentes pesos. Revista Brasileira de Zootecnia, v.36, n.4, p.978-986, 2007.

RUSSELL, J.B.; WILSON, DB. Why are ruminal cellulolytic bacteria unable to digest cellulose at low $\mathrm{pH}$ ? Journal of Dairy Science, v.79, p.1503-1509, 1996.

SILVA, D.J. QUEIROZ, A.C. Análise de alimentos (métodos químicos e biológicos). 2.ed. Viçosa, MG: Universidade Federal de Viçosa, 2002. 165 p.

SILVA, N.R. Desempenho produtivo de bovinos de corte alimentados com dietas contendo diferentes níveis de farelo do mesocarpo do babaçu. 2008. 75f. Dissertação (Mestrado em Ciência Animal Tropical) - Escola de Medicina Veterinária e Zootecnia, Araguaína.

SNIFFEN, C.J.; O'CONNOR, J.D.; VAN SOEST, P.J. et al. A net carbohydrate and protein system for evaluating cattle diets: II. Carbohydrate and protein availability. Journal of Animal Science, v.70, p.3562-3577, 1992. 